\title{
ALLEVIATION OF LITHIUM TOXICITY IN SORGHUM (SORGHUM VULGARE PERS.) BY INOCULATION WITH LITHIUM RESISTANT BACTERIA
}

\author{
HAYYAT, M. U..$^{1 *}$-KHAN, A. U. ${ }^{1}-$ ALI, S. $^{2}-$ SidDIQ, Z. ${ }^{3}-$ SHARIF, F. ${ }^{1}$ \\ ${ }^{1}$ Sustainable Development Study Centre, Government College University Lahore, Pakistan \\ ${ }^{2}$ Institute of Industrial Biotechnology, Government College University Lahore, Pakistan \\ ${ }^{3}$ Department of Botany, Government College University Lahore, Pakistan \\ ${ }^{*}$ Corresponding author \\ e-mail: umarenv@yahoo.com; phone: +92-321-4032-300
}

(Received 26 ${ }^{\text {th }}$ Apr 2020; accepted $7^{\text {th }}$ Oct 2020)

\begin{abstract}
The present study was carried out to assess the impact of lithium and the alleviation of its influence on the growth and physiological performance of Sorghum vulgare using lithium resistant bacteria. Various growth and physiological parameters were measured at 15 days intervals and plants were harvested after 150 days to assess the lithium up-take in both the above-and belowground parts. A significant reduction in the number of leaves, plant height, panicle number, and grain yield, was observed among the plants treated with lithium. While, these growth parameters exhibited a significant increase among plants inoculated with bacteria. There was not a significant difference on gas exchange rate in the lithium treated plants as compared to the plants treated with bacterial inoculation. A strong significant relationship was observed between lithium concentrations in roots and biomass accumulation factor. Furthermore, the concentration of lithium was significantly lower in above and below-ground parts of plants with bacteria as compared to those treated with lithium only. Our findings demonstrate that lithium can cause significant reduction in growth and yield of sorghum, although reduction can be compensated by applying lithium resistant bacteria. Such data can be useful for lithium remediation in agricultural crops.
\end{abstract}

Keywords: plant growth promoting bacteria, vegetative, yield, physiology, pollution

\section{Introduction}

Pollution, specifically that of soil and water has formulated the crisis for life on earth, wide efforts have been taken to explore solution for this disorder (Brown and Chaney, 2016). Lithium is extremely mobile element geochemically, so, the environmental and occupational health and safety risks are high due to its mobility (Aral and Vecchio-Sadus, 2008). Lithium is toxic to plants, and only a few plant species are also lithium tolerant. Lithium contents concentration may reach up to $1000 \mathrm{\mu gg}^{-1}$ of plant mass (Shahzad et al., 2016). In fact, it is not required for the growth and development of plant. Symptoms of lithium toxicity in plants are mostly chlorosis. Prime uses of lithium in today's daily life is for manufacturing of batteries (39\%) ceramics and glass (30\%) and rest in some other uses. Australia, Chile, China and Argentina are the largest lithium-producing countries in the world respectively (Jaskula, 2019). At present Lithium-ion batteries recycling is paying attention only on collection of economically viable elements like Cobalt and Nickel. Lithium is neglected even in sophisticated recycling systems because it is cheap and easily available for mining of virgin material. Currently lithium pollution is present in the countries where it is extracted and where finally the products of lithium are disposed off without any treatment (Ferreira et al., 2009; Dewulf et al., 2010; Wanger, 2011; Gu et al., 2017; Winslow et al., 2018). 
Currently, there are not much studies about the phytotoxic effects of lithium, hence the metabolic role of lithium in plants is not fully documented (Hawrylak-Nowak et al., 2012; Franzaring et al., 2016). Being soluble in water it forms ions absorbed by plants (Aral and Vecchio-Sadus, 2008). Tolerance and uptake of lithium varies among plant families even in species according to their physiology for the ion up-take. Members of family leguminosae are most affected by lithium (Kabata-Pendias and Mukherjee, 2007). Plant and bacterial interaction has great importance, bacteria are helpful for plants to absorb nutrients and cope with different stresses faced by the plants. Bacteria synthesize plant hormones, which can cause direct effect on plant physiology. Bacteria also increase plant access to soil nutrients, and enhance plant growth. Such interaction result in the form of better growth and yield in plants (Hayat et al., 2010; Nadeem et al., 2014; ThekaKutumela et al., 2020).

Sorghum (Sorghum vulgare Pers.) is an important crop cultivated in most of tropical, subtropical, and temperate regions. It is used worldwide for both cereal grain and fodder purposes. It belongs to $\mathrm{C} 4$ group of plants and have ability to face wide range of stresses (Gill et al., 2014; Zancheta et al., 2015; Jia et al., 2016). To the best of our knowledge the sorghum-bacterial interaction under lithium stress has not been much investigated previously. Major objectives of present study were to: (1) determine the effects of different concentrations of lithium and lithium resistant bacteria inoculation on the growth and yield of sorghum; (2) explore the role of different concentrations of lithium and inoculation of lithium resistant bacteria on the rate of photosynthesis, transpiration and stomatal conductance; (3) assess the uptake patterns (root, shoot and grains) of lithium in terms of bioaccumulation and translocation. For these objectives, we hypothesized that the significant reduction in plant growth and their physiology will be caused by the lithium, further the inoculation of lithium resistant bacteria will compensate the lithium effects. It was also hypothesized that there may be the relationship of lithium concentrations in plant parts and biomass accumulation factor. Findings of this study will add to understand tolerance of lithium toxicity in sorghum, and will provide eco-friendly approach to implement in the field.

\section{Materials and Methods}

\section{Study site and experimentation}

The pot experiment was conducted in the wire house of Botanic Garden GC University Lahore, Pakistan, containing Sorghum vulgare Pers. (sorghum) following the factorial experiment in a completely randomized design. Earthen pots of $35.56 \mathrm{~cm}$ diameter were used in this experiment, at start three seeds were sown in each pot, when plants were established, thinning was carried out and only one plant per pot was remained. There were six replicate pots per treatment and total of five treatments for lithium $(0,50,100,150$ and $200 \mathrm{ppm}$ and were labelled as T0, T1, T2, T3, T4) and five treatments for lithium and bacterial inoculations were applied (labelled as T0SB, T1SB, T2SB, T3SB, T4SB). Inoculum of lithium resistant bacteria (isolated from soil and identified as Bacillus velezensis) was prepared by dissolving eight gram of nutrient broth in some amount of distilled water and final volume was raised to one liter with the help of distilled water. This broth was added to flasks in which isolated lithium resistant bacterial colonies were added and kept at $37^{\circ} \mathrm{C}$ for 24 hours. Then $10 \mathrm{~mL}$ of liquid nutrient broth containing lithium resistant bacteria $\left(10^{7} \mathrm{CFU} \mathrm{ml} \mathrm{m}^{-1}\right)$ was mixed with $40 \mathrm{~mL}$ distilled water and was 
poured into pots. The experiment was conducted for 150 days, and plants were destructively harvested.

\section{Growth, yield and physiological assessment}

During experiment biomass production was monitored through both physical and physiological parameters (Aslam et al., 2007). The parameters for growth included, number of leaves per plant, and total plant height of plant $(\mathrm{cm})$, which were measured every 15 days. While the physiological parameters included the leaf area based maximum rate of photosynthesis, maximum stomatal conductance, rate of maximum transpiration using IRGA LCA4, in the ambient conditions in the morning time from 10:30 am to 11:30 am. These measurements were taken three times of study duration (first week of start of experiment, at the time of flowering and before the final harvest with mature seeds). The chlorophyll contents were measured using spectrophotometer (Spectroscan 80D). After final harvest, length of roots and shoots, fresh and dry mass of roots and shoots, number of panicle and grain yield were estimated in the Plant Eco-physiology Laboratory of GC University Lahore.

\section{Determination of lithium}

Plant material was placed in a porcelain crucible, which were placed in a muffle furnace for 5 hours at $550^{\circ} \mathrm{C}$ for the preparation of ash. Ash of plant material was taken and dissolved in $5 \mathrm{~mL}$ of $2 \mathrm{~N} \mathrm{HCl}$ solution and mixed with a stirrer. After fifteen minutes, the final volume was raised to $50 \mathrm{~mL}$ with the help of distilled water. The solution was mixed with the help of stirrer and then it was filtered by using Whattman No. 42 filter paper. The extract was collected in a flask and lithium was measured by flame photometer (S20 Spectrolab).

Translocation factor was calculated by following the method of Marchiol et al. (2004). Bioaccumulation factor (BAF) was computed according to Ruus et al. (2005).

\section{Statistical analysis}

The results obtained in experiment were expressed in terms of means and standard deviations. Data was statistically analyzed using one way ANOVA (Duncan's Multiple Range test (DMRT)) involving the comparison of the means of each treatment having the lithium application with the means of each treatment having the lithium application but also with the bacterial inoculation for each studied parameters. The statistical analyses, correlations between parameters and graphics were carried out using software Sigma Plot 12.5 version.

\section{Results}

\section{Effect of lithium and bacterial inoculation on growth and yield of sorghum}

A significant decreasing trend of number of leaves was observed from the T0 to T4 during the experiment duration of 150 days, but the significant increase in the number of leaves was observed in the treatment of TOSB as compared to T0 in all the observations (Fig. 1). There was also the significant increase in the number of leaves in T1SB as compared to $\mathrm{T} 1$ in 30 days observation and the similar significant difference was observed in 75 days, and 105 days duration. The significant increase in the number of leaves was also observed in T3SB as compared to T3 in 60, 90135 and 150 days duration (Fig. 1). 
The significant increase in leaves number was observed in T3SB in 135 and 150 days duration. In the T4SB the significant increase in the number of leaves was only observed in 150 days duration (Fig. 1). Overall, among all the treatments, significant increase in the total number of leaves was observed, except, in the means of T2, T2SB during 30, 45 and 90 days duration. The similar non-significant difference was observed between the means of T1, T1SB in 45 and 120 days duration. The non-significant difference was also observed between T4, T4SB in 45, 60 and 90 days duration (Table S1).

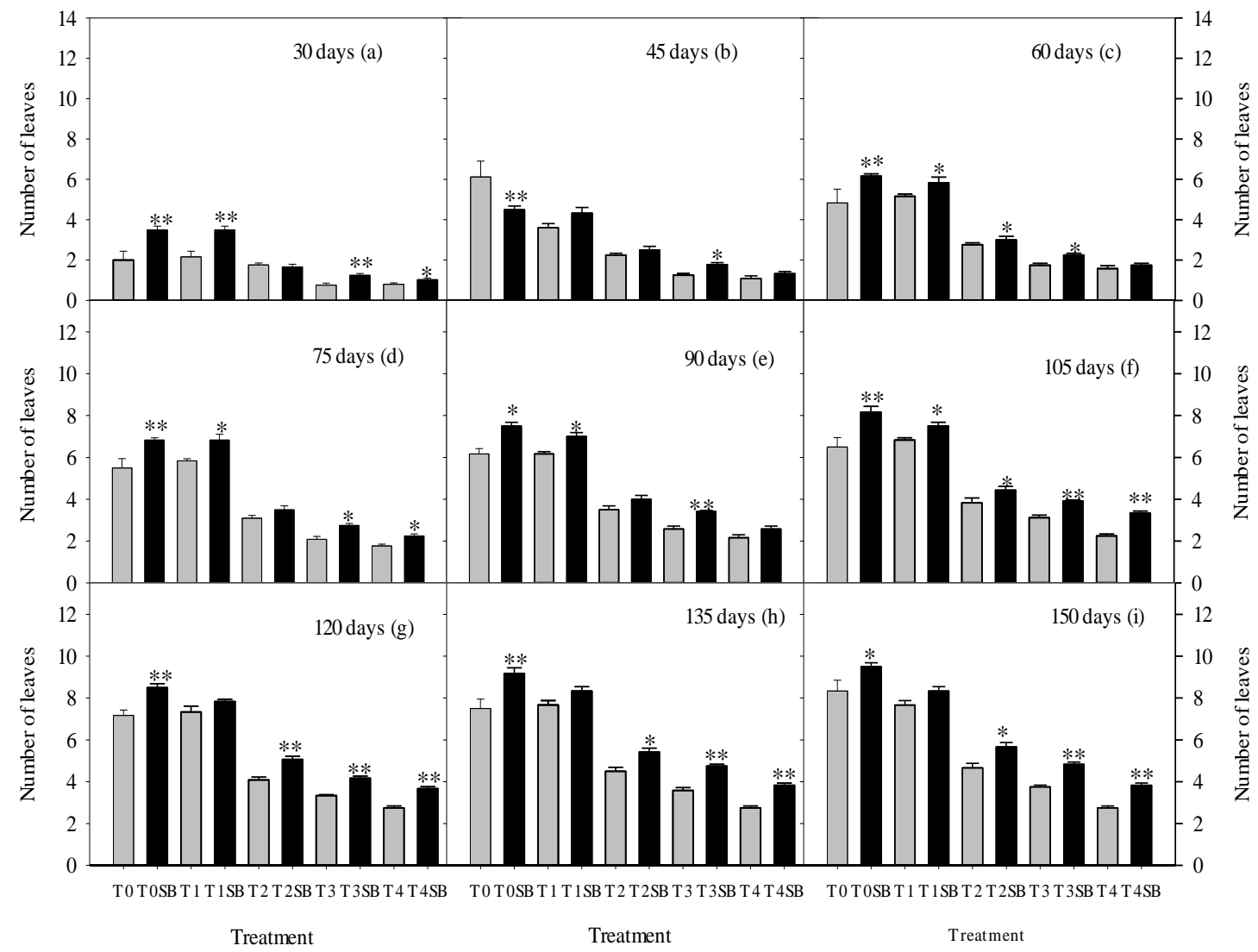

Figure 1. Mean of the total number of leaves per plant for each treatment with the number of days having 15 days intervals from 30-150 days. Where *** indicate $P<0.0001, * * P<0.001$ and $* P<0.05$. Grey bars indicate the soil with Lithium treatment, while black bars indicate the soil with Lithium treatment and also application of bacteria. Error bars indicate $S E( \pm)$

A significant decrease in the total height of sorghum plants was observed from $\mathrm{T} 0$ to T4 during the 150 days of experiment, but the significant increase in the plant height was observed in all the treatments having the soil with lithium but also inoculated with bacteria as compared to those having the lithium application only (Fig. 2). The significant increase in plant height was observed in TOSB as compared to T0 in 30 and 150 days duration only (Fig. 2). The similar significant increase in the plant height was also observed in T1SB, T2SB and T3SB as compared to T1, T2 and T3 in all the studied observations. While there was the consistent significant increase in plant height for T4SB as compared to $\mathrm{T} 4$ in all durations except the 30 days duration (Fig. 2). The non-significant increase in plant height was only observed between the mean of T0, T0SB at 60 days duration (Table $S 2$ ). 


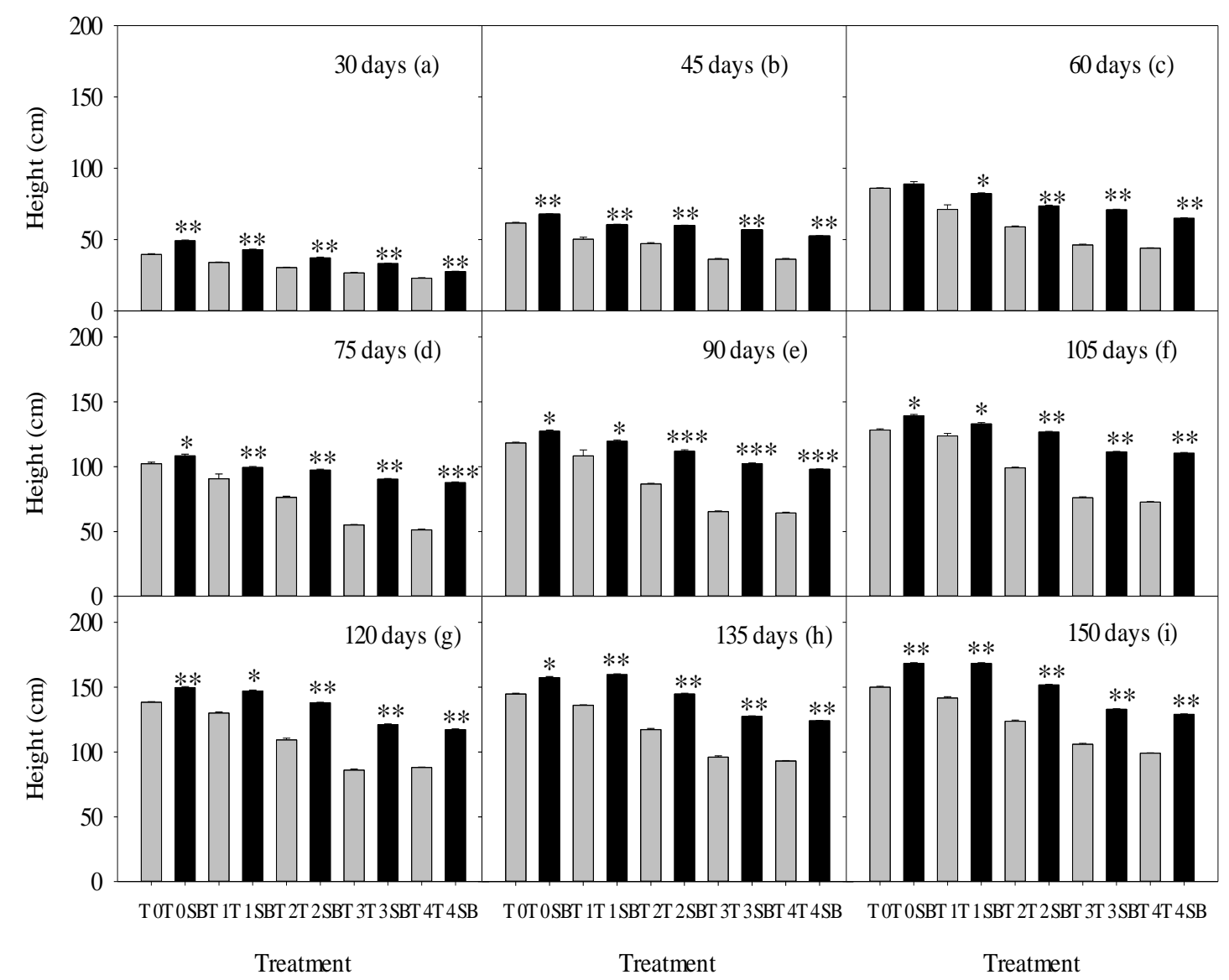

Figure 2. Mean total height of plants for each treatment with the number of days having 15 days intervals from 30-150 days. Where $* * *$ indicate $P<0.0001$, $* * P<0.001$ and $* P<0.05$.

Grey bars indicate the soil with Lithium treatment, while black bars indicate the soil with Lithium treatment and also application of bacteria. Error bars indicate $S E( \pm)$

The consistent decrease in the panicle number per plant, panicle length, number of grains and grains yield was also observed across all treatments T0 to T4, while the significant increase in panicle number per plant, panicle length, number of grains and grains yield was observed in all treatments T0SB to T4SB (Fig. 3). While there was not the significant difference in the number of panicles for T1 and T1SB, T4 and T4SB, this non-significant difference was observed panicle length for T1 and T1SB (Table S3).

\section{Effect of lithium and bacterial inoculation on gas exchange, biomass and lithium contents in sorghum}

A significant increase in the rate of maximum photosynthesis, stomatal conductance and rate of transpiration was observed from the initial week to the flowering time till the measurements taken during the seed maturation, the flowering time measurements were also significantly larger than the measurements of seed maturation time in the T0, T0SB to T2, T2SB (Fig. 4a-i). While there was a significant increase in the rate of maximum photosynthesis, stomatal conductance and rate of transpiration from the initial week to the flowering time till seed maturation (Fig. 4j-o, Table S4). 


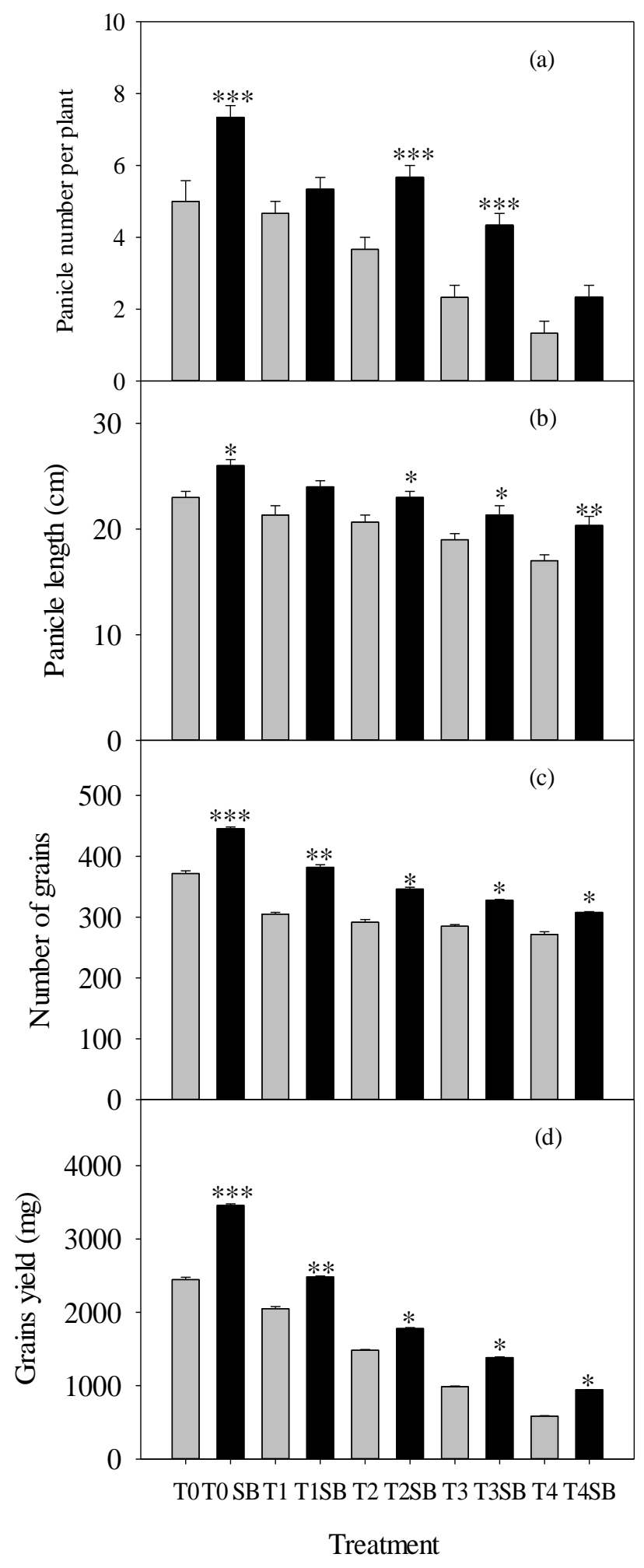

Figure 3. Mean panicle number per plant (a), panicle length $(b)$, total number of grains per plant (c), and grain yield (d) for each treatment. Where *** indicate $P<0.0001, * * P<0.001$ and $* P<0.05$. Grey bars indicate the soil with Lithium treatment, while black bars indicate the soil with Lithium treatment and also application of bacteria. Error bars indicate $S E( \pm)$ 

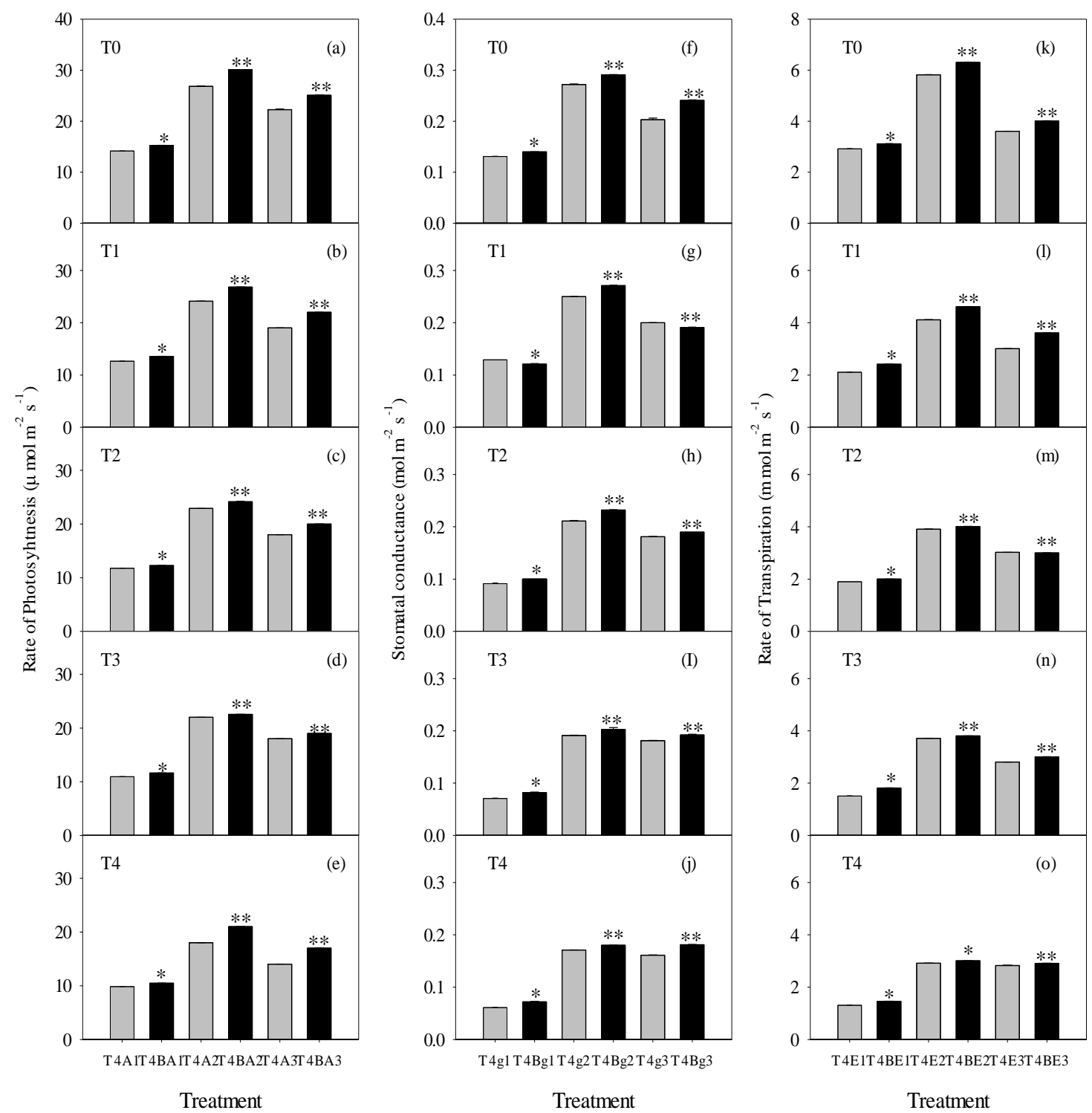

Figure 4. Mean of the maximum rate of photosynthesis, maximum stomatal conductance, rate of maximum transpiration at the first week of start of experiment, at the time of flowering and before the final harvest with mature seeds. Where *** indicate $P<0.0001, * * P<0.001$ and * $P<0.05$. Grey bars indicate the soil with Lithium treatment, while black bars indicate the soil with Lithium treatment and also application of bacteria. Error bars indicate SE ( \pm )

There was not a significant increase in the shoot and root fresh weight, shoot and root dry weight, and root fresh and dry weight in T0 and T0SB and T1SB (Fig. 5). The non-significant difference in root fresh weight was also observed between T1 and T1SB, and T3 and T3SB, as well as between root dry weight of T3 and T3SB and T4 and T4SB. Specific root length and specific shoot length was observed across all the treatments from T0, T0SB to T4, T4SB (Fig. 5e,f). The comparison all the remaining treatments indicated the significant differences between the lithium treatments and the bacterial inoculations (Fig. 5, Table S5). 


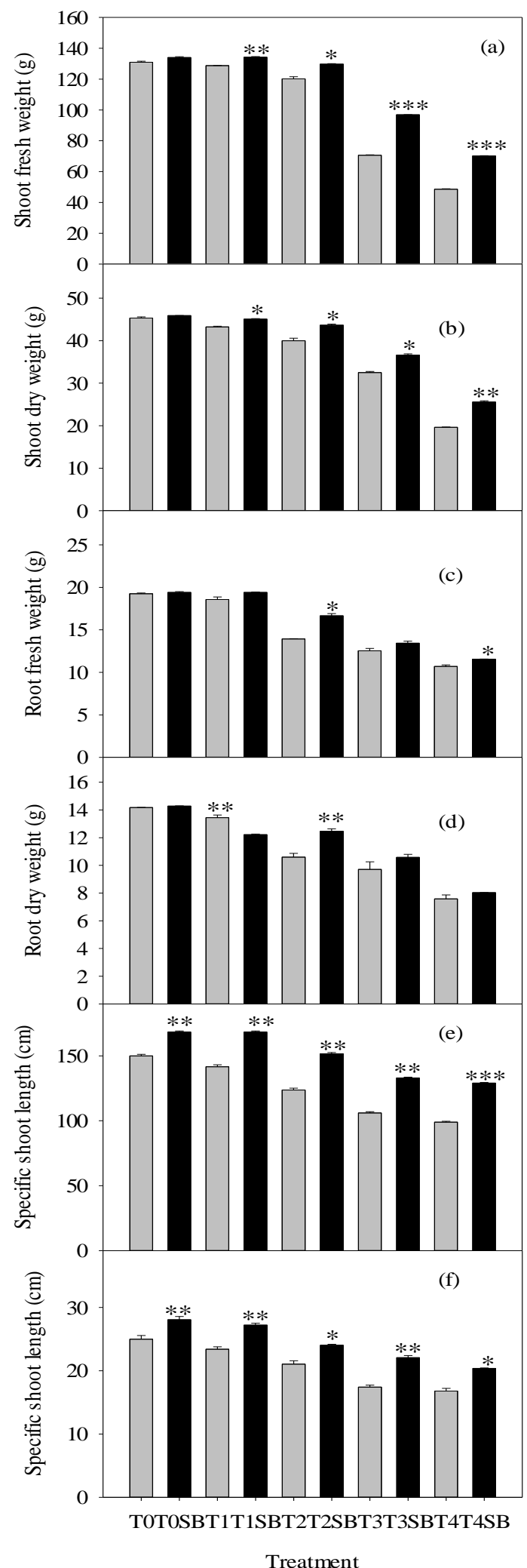

Figure 5. Mean fresh and dry weight of shoot $(a, b)$ mean fresh and dry weight of root $(c, d)$ mean specific shoot length and root length $(e, f)$ for each treatment. Where $* * *$ indicate $P<$ $0.0001, * * P<0.001$ and $* P<0.05$. Grey bars indicate the soil with Lithium treatment and black bars indicate the soil with Lithium treatment and also application of bacteria. Error bars indicate $S E( \pm)$ 
Similarly, the non-significant difference in chlorophyll a and chlorophyll $\mathrm{b}$ was observed between $\mathrm{T} 1$ and T1SB, and T0 and T0SB, respectively (Fig. 6a,c). For the rest of treatments there was a significant difference in the studied chlorophyll contents (Table S6).

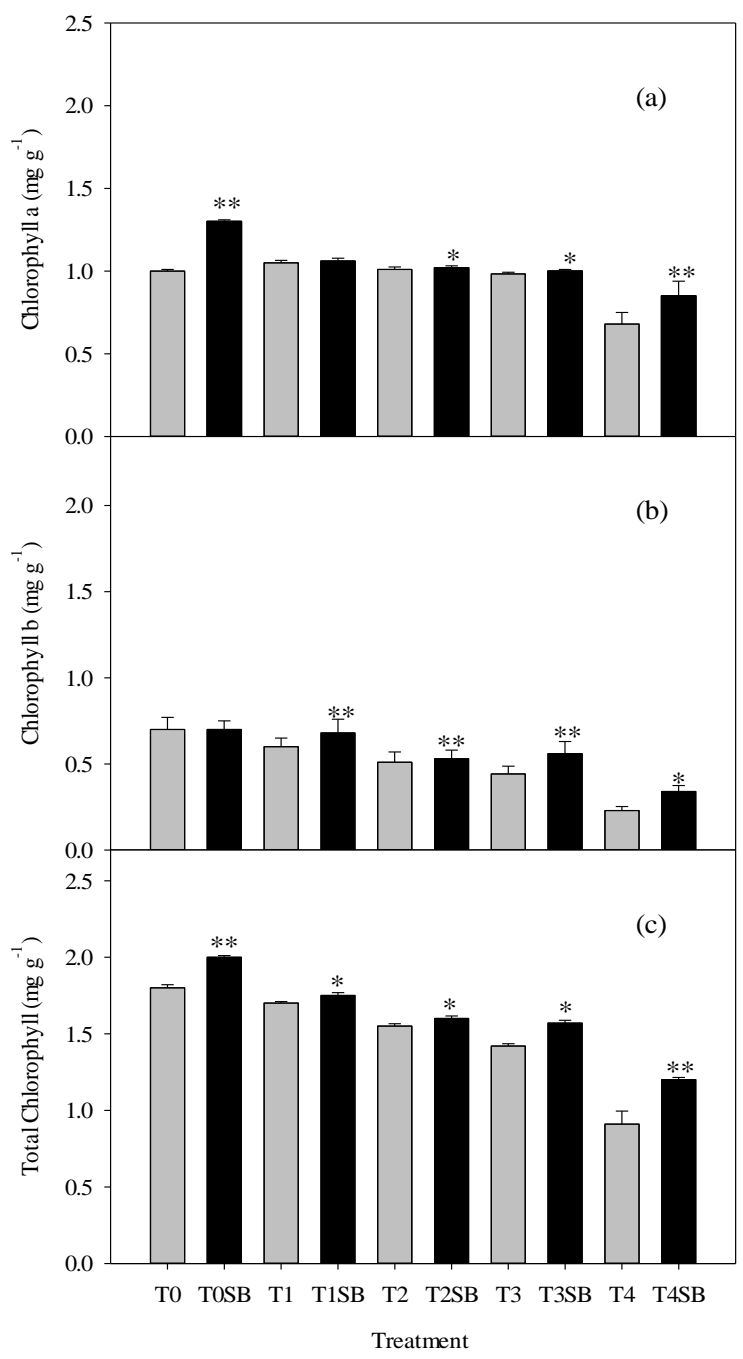

Figure 6. Mean chlorophyll a (a), chlorophyll b (b) and total chlorophyll (c) for each treatment. Where *** indicate $P<0.0001$, ** $P<0.001$ and $* P<0.05$. Grey bars indicate the soil with Lithium treatment, while black bars indicate soil with Lithium treatment and also application of bacteria. Error bars indicate $S E( \pm)$

A strong significant and positive relationship was observed between lithium concentration in roots with biomass accumulation factor (Fig. 7a). But, the slope of relationship was significantly different for the roots of plants with lithium concentration and application bacterial inoculation. Similarly, the lithium concentration in roots was also significantly and positively related to lithium concentration in grains (Fig. $7 b$ ). The translocation factor was significantly and positively associated with biomass accumulation factor across all the treatments of lithium, while translocation factor was significantly and negatively associated with biomass accumulation factor for the plants having lithium with bacterial inoculation (Fig. $8 a, b)$. 


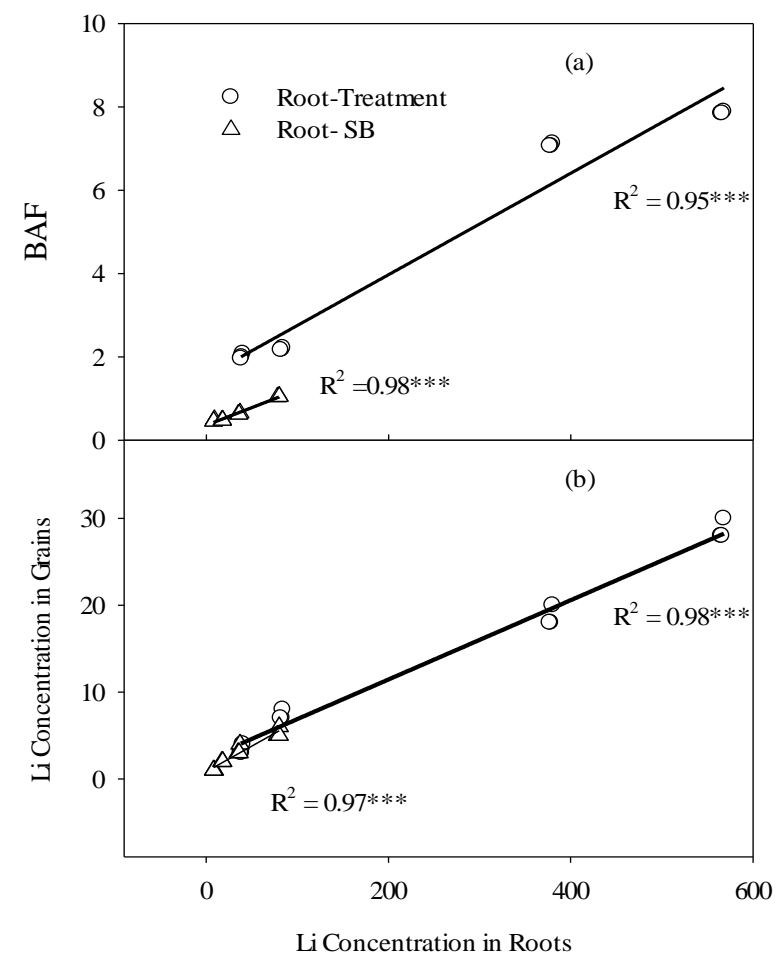

Figure 7. Relationship of Lithium concentration in roots with Biomass Accumulation Factor (a) and the Lithium concentration in grains $(b)$. Where $* * *$ indicate $P<0.0001, * * P<0.001$ and * $P<0.05$

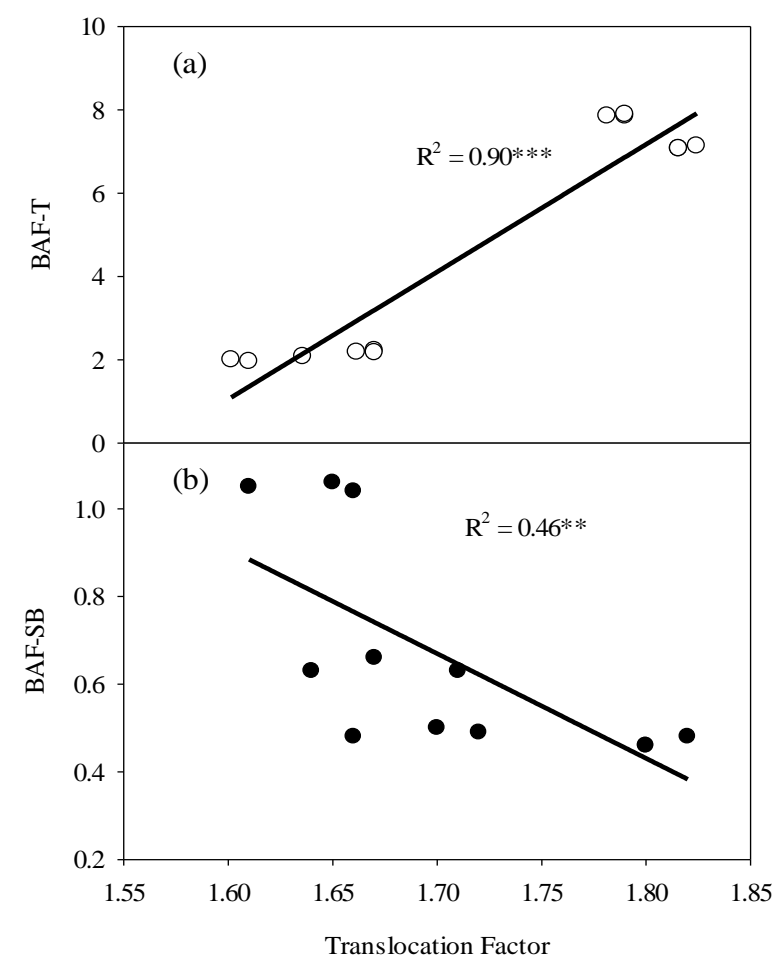

Figure 8. Relationship of translocation factor with Biomass Accumulation Factor having Lithium treatment (a) and with Biomass Accumulation Factor inoculated with Bacteria (b).

Where $* * *$ indicate $P<0.0001, * * P<0.001$ and $* P<0.05$ 
In all the plant parts, roots, shoots and grains the lithium was significantly lower in the plant parts which were inoculated with bacteria as compared to the plant parts having the application of various lithium concentrations (Fig. 9a-c). The lithium concentration was maximum in shoot, followed by the root and the minimum lithium was up-taken by the seeds (Table S7).

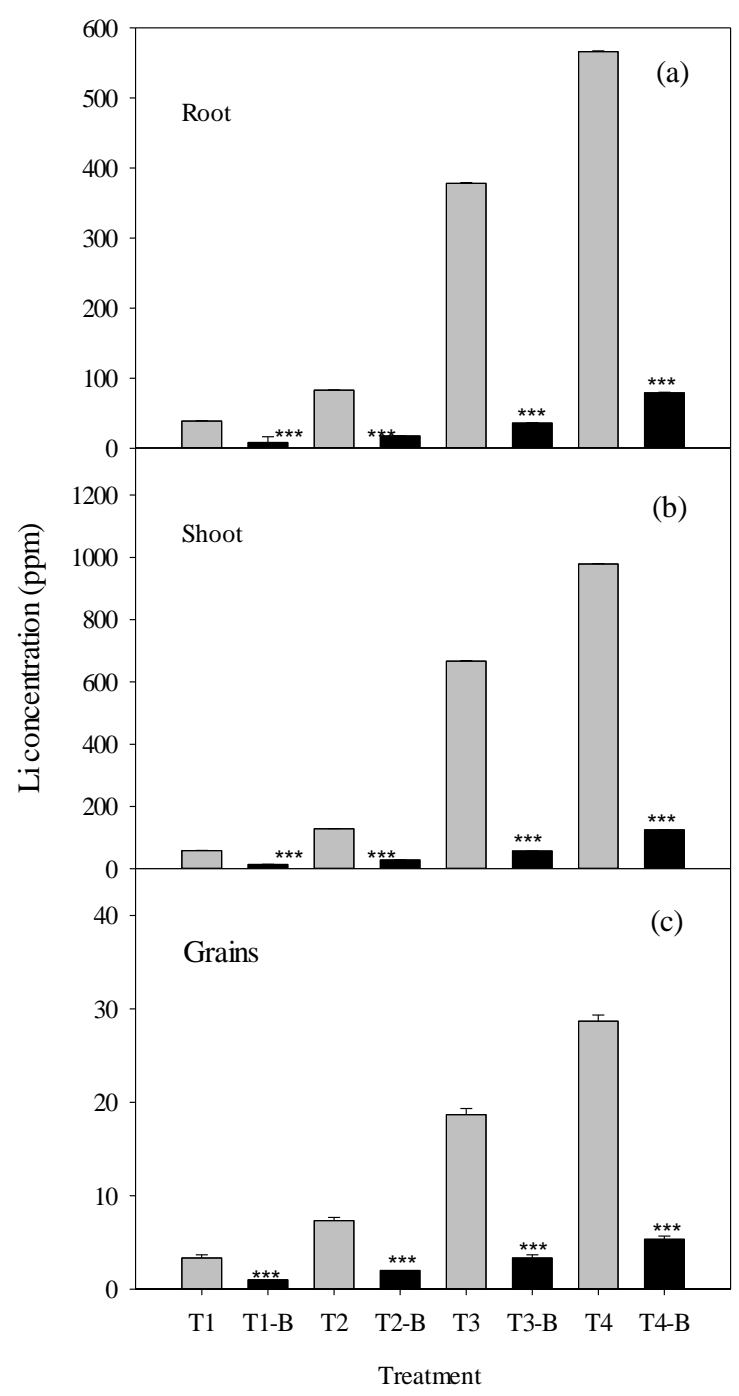

Figure 9. Lithium concentration in roots (a), shoots (b) and grains (c) for each treatment, where $* * *$ indicate $P<0.0001$. Grey bars indicate the soil with Li treatment and black bars indicate the soil with Li treatment and also application of bacteria. Error bars indicate $S E$ ( \pm )

\section{Discussion}

Our study demonstrates that the lithium can impact the growth and yield of sorghum, but the application of bacteria can alleviate the impact. This supports our hypothesis and also highlights the importance of lithium resistant bacteria application in the remediating the lithium pollution for the studied species. Our results demonstrate that lithium significantly reduced the growth of plants, but the growth was compensated through the lithium resistant bacteria. As hypothesized, we found the strong relationship of lithium concentration roots and grains. In most of lithium treatments and the observations made 
during the experiment, significant reduction in the number of leaves and plant height, panicle number, number of grains and grain yield indicating the overall reduction in plants growth and yield. This pattern was also reflected in the fresh and dry weight of above and below ground parts of plants. Such reductions indicate that the applied lithium concentration was toxic to sorghum. Our findings support the findings of Aral and Vecchio-Sadus (2008) who found the reduction in Citrus with lithium concentration. While, contradict with Schrauzer (2002), Kabata-Pendias and Mukherjee (2007) reporting the less impact on the growth of plants from Asteraceae, and Solanaceae when the lithium was applied in their soil.

We did not find the significant reduction in the area based rate of maximum photosynthesis, stomatal conductance, and transpiration which could be because of the reduction of number of leaves. The plant can have the adjustments in its gas exchange while exposed to some abiotic stress. The similar pattern was observed for most of treatment on chlorophyll contents, except for the T4, where all the chlorophyll a, b and total chlorophyll showed the significant increase when the bacterial inoculation was applied. Indicating the compensatory effect of bacterial inoculation.

We found that the significant and positive relationship between the lithium concentration in roots and biomass accumulation factor, but the inoculation of bacteria resulted in a significantly reduced slope for the relationship of BAF and lithium concentration in the roots. Indicating a mechanism in which bacteria would have work to reduce the effect of lithium. The similar pattern was observed for the lithium concentration in roots and lithium concentration in grains (Anjum et al., 2015). Such interaction between plant and microbes result in the formation of biofilm around the roots of plant. Successful colonization of microbes in the form of biofilm provides efficient shield to the plants against various stresses. There are different mechanisms involve to cope abiotic and biotic stresses via biofilm formation one of them is the production of exopolysaccharides. These exopolysaccharides are not only helpful against high ionic contents but also retain water and nutrients in these stressful conditions (Qurashi and Sabri, 2012; Kasim et al., 2016). This was supported by the results of our Fig. 9, where we observed highly significant reduction in lithium concentration in the plant parts, i.e., root, shoot, and grains. We found that the maximum concentration of lithium was found in shoot, followed by root and the minimum concentration was found in grains. This could be due to the plant mass accumulation to different organs. But in general, our results support the findings of (Jurkowska et al., 1998, 2003) in terms of lithium concentration to different parts of the plant.

\section{Conclusion}

Our study concludes that sorghum is susceptible to the lithium, when applied in the soil. As the significant reduction in the growth and yield were observed. Although, there was compensation for the reduction of growth by introducing the lithium resistant bacteria. The findings are useful for the cultivation of sorghum in particular and other cultivated crops in general, especially with reference to the lithium. Mechanisms of tolerance for $\mathrm{Li}$ are not yet clear and much work is underway to elucidate mechanisms of tolerance because of the consequences of $\mathrm{Li}$ is still poorly represented in many ecosystems. Li-pollution becoming a big environmental issue and having adverse implications for animals and plants like human update to these problems are crucial and require more detailed research. 
Acknowledgements. We gratefully acknowledge the generous support of GC University Lahore Pakistan to finance the present study. The help of gardeners at Botanic Garden is also acknowledged.

Conflict of interests. The authors declared that there is no conflict of interests regarding the publication of this paper.

\section{REFERENCES}

[1] Anjum, S. A., Tanveer, M., Hussain, S., Bao, M., Wang, L., Khan, I., Ullah, E., Tung, S. A., Samad, R. A., Shahzad, B. (2015): Cadmium toxicity in maize (Zea mays L.): Consequences on antioxidative systems, reactive oxygen species and cadmium accumulation. - Environmental Science and Pollution Research 22(21): 17022-17030.

[2] Aral, H., Vecchio-Sadus, A. (2008): Toxicity of lithium to humans and the environment a literature review. - Ecotoxicology and Environmental Safety 70(3): 349-356.

[3] Aslam, M. M., Malik, M., Baig, M. A., Qazi, I. A., Iqbal, J. (2007): Treatment performance of compost-based and gravel-based vertical flow wetlands operated identically for refinery wastewater treatment in Pakistan. - Ecological Engineering 30: 34-42.

[4] Brown, S. L., Chaney, R. L. (2016): Use of amendments to restore exosystems to metal mining-impacted sites: tools to evaluate efficacy. - Current Pollution Report 2: 91-102.

[5] Dewulf, J., Vorst, G. V., Denturck, K., Langenhove, H. V., Ghyoot, W., Tytgat, J., Vandeputte, K. (2010): Recycling rechargeable lithium ion batteries: critical analysis of natural resource savings. - Resources, Conservation and Recycling 54(4): 229-234.

[6] Ferreira, D. A., Prados, L. M. Z., Majuste, D., Mansur, M. B. (2009): Hydrometallurgical separation of aluminum, cobalt, copper and lithium from spent Li-ion batteries. - Journal of Power Sources 187(1): 238-246.

[7] Franzaring, J., Schlosser, S., Damsohn, W., Fangmeier, A. (2016): Regional differences in plant levels and investigations on the phytotoxicity of lithium. - Environmental Pollution 216: 858-865.

[8] Gill, J. R., Burks, P. S., Staggenborg, S. A., Odvody, G. N., Heiniger, R. W., Macoon, B., Moore, K. J., Barrett, M., Rooney, W. L. (2014): Yield results and stability analysis from the sorghum regional biomass feedstock trial. - BioEnergy Research 7: 1026-1034.

[9] Gu, F., Guo, J., Yao, X., Summers, P. A., Widijatmoko, S. D., Hall, P. (2017): An investigation of the current status of recycling spent lithium-ion batteries from consumer electronics in China. - Journal of Cleaner Production 161: 765-780.

[10] Hawrylak-Nowak, B., Kalinowska, M., Szymańska, M. (2012): A study on selected physiological parameters of plants grown under lithium supplementation. - Biological Trace Element Research 149(3): 425-430.

[11] Hayat, R., Ali, S., Amara, U., Khalid, R., Ahmed, I. (2010): Soil beneficial bacteria and their role in plant growth promotion: a review. - Annals of Microbiology 60(4): 579-598.

[12] Jaskula, B. (2019): Lithium. Mineral Commodity Summary. - United States Geological Survey.

[13] Jia, W. T., Lv, S. L., Feng, J. J., Li, J. H., Li, Y. X., Li, S. Z. (2016): Morphophysiological characteristic analysis demonstrated the potential of sweet sorghum (Sorghum bicolor (L.) Moench) in the phytoremediation of cadmium-contaminated soils. - Environmental Science and Pollution Research 23: 18823-18831.

[14] Jurkowska, H., Rogóż, A., Wojciechowicz, T. (1998): Comparison of lithium toxic influence on some cultivars of oats, maize and spinach. - Acta Agraria et Silvestria. Series Agraria 36: 37-42. (in Polish).

[15] Jurkowska, H., Rogóż, H., Wojciechowicz, T. (2003): Phytotoxicityof lithium on various soils. - Polish Journal of Soil Science 36(1): 71-76.

[16] Kabata-Pendias, A., Mukherjee, A. B. (2007): Trace elements from soil to human. Springer-Verlag Berlin Heidelberg. 
[17] Kasim, W. A., Gaafar, R. M., Abou-Ali, R. M., Omar, N. M., Hewait, H. M. (2016): Effect of biofilm forming plant growth promoting rhizobacteria on salinity tolerance in barley. Annals of Agricultural Science 61(2): 217-227.

[18] Marchiol, L., Sacco, P., Assolari, S., Zerbi, G. (2004): Reclamation of polluted soil: phytoremediation potential of crop-related Brassica Species. - Water, Air and Soil Pollution 158: 345-356.

[19] Nadeem, S. M., Ahmad, M., Zahir, Z. A., Javaid, A., Ashraf, M. (2014): The role of mycorrhizae and plant growth promoting rhizobacteria (PGPR) in improving crop productivity under stressful environments. - Biotechnology Advances 32(2): 429-448.

[20] Qurashi, A. W., Sabri, A. N. (2012): Bacterial exopolysaccharide and biofilm formation stimulate chickpea growth and soil aggregation under salt stress. - Brazilian Journal of Microbiology 43(3): 1183-1191.

[21] Ruus, A., Schaanning, M., Øxnevad, S., Hylland, K. (2005): Experimental results on bioaccumulation of metals and organic contaminants from marine sediments. - Aquatic Toxicology 72(3): 273-292.

[22] Schrauzer, G. N. (2002): Lithium: Occurrence, Dietary Intakes, Nutritional Essentiality. Journal of American College Nutrition 21(1): 14-21.

[23] Shahzad, B., Tanveer, M., Hassan, W., Shah, A. N., Anjum, S. A., Cheema, S. A., Ali, I. (2016): Lithium toxicity in plants: Reasons, mechanisms and remediation possibilities - A review. - Plant Physiology and Biochemistry 107: 104-115.

[24] Theka-Kutumela, M. P., Kanu, S. A., Araya, H. T., Sedibe, M. M., Mudau, F. N. (2020): Physiological and phytochemical responses of baby spinach (Spinacia oleracea L.) cultivars to combined npks nutrition and Bacillus subtilis BD233 inoculation using LCMS. - Applied Ecology and Environmental Research 18(2): 2129-2140.

[25] Wanger, T. C. (2011): The Lithium future-resources, recycling, and the environment. Conservation Letters 4: 202-206.

[26] Winslow, K. M., Laux, S. J., Townsend, T. G. (2018): A review on the growing concern and potential management strategies of waste lithium-ion batteries. - Resources Conservation and Recycling 129: 263-277.

[27] Zancheta, A. C., De Abreu, C. A., Zambrosi, F. C., Erismann, N. D., Lagoa, A. M. (2015): Cadmium accumulation by jack-bean and sorghum in hydroponic culture. - International Journal of Phytoremediation 17(3): 298-303. 


\section{SUPPLEMENTARY INFORMATION}

Table S1. One Way ANOVA showing the comparison of mean values number of leaves for each treatment, where T0, indicates the soil without lithium and bacterial inoculation, T1, T2, T3, T4 indicate the application of different concentration of lithium and TOSB, indicates the soil without lithium application but with the inoculation of bacteria, T1SB, T2SB, T3SB and $T 4 S B$ indicate the different concentrations of lithium with the application of bacterial inoculations

\begin{tabular}{|c|c|c|c|c|c|}
\hline \multicolumn{6}{|c|}{ Total number of leaves in different durations } \\
\hline Treatment & Duration (Days) & Mean $( \pm$ SE) & MS & $\mathbf{F}$ & $P$ \\
\hline T0, T0SB & 30 & $2.00(0.18)-3.5(0.18)$ & 6.75 & 33.75 & $<0.001$ \\
\hline $\mathrm{T} 1, \mathrm{~T} 1 \mathrm{SB}$ & 30 & $2.16(0.27)-3.5(0.18)$ & 5.33 & 16.0 & 0.003 \\
\hline $\mathrm{T} 2, \mathrm{~T} 2 \mathrm{SB}$ & 30 & $1.76(0.09)-1.6(0.31)$ & 0.030 & 0.402 & 0.54 \\
\hline T3, T3SB & 30 & $0.76(0.09)-1.25(0.09)$ & 0.701 & 13.92 & 0.004 \\
\hline $\mathrm{T} 4, \mathrm{~T} 4 \mathrm{SB}$ & 30 & $0.80(0.07)-1.03(0.07)$ & 0.163 & 5.05 & 0.048 \\
\hline T0, T0SB & 45 & $3.5(0.18)-4.5(0.18)$ & 3.00 & 15.0 & 0.003 \\
\hline $\mathrm{T} 1, \mathrm{~T} 1 \mathrm{SB}$ & 45 & $3.66(0.21)-4.33(0.27)$ & 1.33 & 3.3 & 0.086 \\
\hline $\mathrm{T} 2, \mathrm{~T} 2 \mathrm{SB}$ & 45 & $2.50(0.09)-2.50(0.18)$ & 0.18 & 1.5 & 0.24 \\
\hline T3, T3SB & 45 & $1.25(0.09)-1.80(0.09)$ & 0.85 & 16.62 & 0.002 \\
\hline $\mathrm{T} 4, \mathrm{~T} 4 \mathrm{SB}$ & 45 & $1.080 .13)-1.33(0.10)$ & 0.188 & 2.04 & 0.183 \\
\hline T0, T0SB & 60 & $4.83(0.27)-6.16(0.10)$ & 5.33 & 20.00 & 0.001 \\
\hline $\mathrm{T} 1, \mathrm{~T} 1 \mathrm{SB}$ & 60 & $5.16(0.10)-5.83(0.27)$ & 1.33 & 5.00 & 0.049 \\
\hline $\mathrm{T} 2, \mathrm{~T} 2 \mathrm{SB}$ & 60 & $2.76(0.09)-3.0(0.18)$ & 0.163 & 1.30 & 0.28 \\
\hline T3, T3SB & 60 & $1.75(0.09)-2.25(0.09)$ & 0.75 & 15.00 & 0.003 \\
\hline $\mathrm{T} 4, \mathrm{~T} 4 \mathrm{SB}$ & 60 & $1.58(0.13)-1.75(0.09)$ & 0.083 & 1.0 & 0.34 \\
\hline $\mathrm{T} 0, \mathrm{~T} 0 \mathrm{SB}$ & 75 & $5.50(0.18)-6.83(0.10)$ & 5.33 & 40 & $<0.001$ \\
\hline $\mathrm{T} 1, \mathrm{~T} 1 \mathrm{SB}$ & 75 & $5.83(0.10)-6.83(0.27)$ & 3.00 & 11.25 & 0.007 \\
\hline $\mathrm{T} 2, \mathrm{~T} 2 \mathrm{SB}$ & 75 & $3.10(0.13)-3.50(0.18)$ & 0.48 & 3.15 & 0.11 \\
\hline T3, T3SB & 75 & $2.08(0.13)-2.75(0.09)$ & 1.33 & 16.0 & 0.003 \\
\hline $\mathrm{T} 4, \mathrm{~T} 4 \mathrm{SB}$ & 75 & $1.76(0.09)-2.75(0.09)$ & 2.90 & 57.63 & $<0.001$ \\
\hline T0, T0SB & 90 & $6.16(0.10)-7.50(0.18)$ & 5.33 & 40.0 & $<0.001$ \\
\hline $\mathrm{T} 1, \mathrm{~T} 1 \mathrm{SB}$ & 90 & $6.17(0.15)-7.0(0.18)$ & 2.08 & 15.62 & 0.003 \\
\hline $\mathrm{T} 2, \mathrm{~T} 2 \mathrm{SB}$ & 90 & $3.5(0.18)-4.00(0.18)$ & 0.75 & 3.75 & 0.082 \\
\hline T3, T3SB & 90 & $2.58(0.13)-3.41(0.05)$ & 2.08 & 31.25 & $<0.001$ \\
\hline $\mathrm{T} 4, \mathrm{~T} 4 \mathrm{SB}$ & 90 & $2.16(0.13)-2.58(0.13)$ & 0.52 & 4.46 & 0.061 \\
\hline T0, T0SB & 105 & $6.50(0.18)-8.16(0.27)$ & 8.33 & 25.0 & $<0.001$ \\
\hline $\mathrm{T} 1, \mathrm{~T} 1 \mathrm{SB}$ & 105 & $6.83(0.10)-7.50(0.18)$ & 1.33 & 10.0 & 0.01 \\
\hline $\mathrm{T} 2, \mathrm{~T} 2 \mathrm{SB}$ & 105 & $3.83(0.23)-4.43(0.18)$ & 1.08 & 4.09 & 0.071 \\
\hline T3, T3SB & 105 & $3.17(0.12)-4.0(0.05)$ & 1.92 & 35.12 & $<0.001$ \\
\hline $\mathrm{T} 4, \mathrm{~T} 4 \mathrm{SB}$ & 105 & $2.25(0.09)-3.33(0.10)$ & 3.52 & 60.35 & $<0.001$ \\
\hline T0, T0SB & 120 & $7.16(0.10)-8.50(0.18)$ & 5.33 & 40.00 & $<0.001$ \\
\hline $\mathrm{T} 1, \mathrm{~T} 1 \mathrm{SB}$ & 120 & $7.33(0.27)-7.83(0.10)$ & 0.75 & 2.81 & 0.12 \\
\hline $\mathrm{T} 2, \mathrm{~T} 2 \mathrm{SB}$ & 120 & $4.08(0.13)-5.06(0.14)$ & 2.90 & 23.45 & $<0.001$ \\
\hline T3, T3SB & 120 & $3.33(0.05)-4.12(0.10)$ & 2.08 & 50.00 & $<0.001$ \\
\hline $\mathrm{T} 4, \mathrm{~T} 4 \mathrm{SB}$ & 120 & $7.66(0.21)-8.33(0.21)$ & 1.33 & 5.00 & 0.05 \\
\hline T0, T0SB & 135 & $7.5(0.18)-9.16(0.27)$ & 8.33 & 25.00 & $<0.001$ \\
\hline T1, T1SB & 135 & $7.66(0.21)-8.33(0.21)$ & 1.33 & 5.00 & 0.05 \\
\hline $\mathrm{T} 2, \mathrm{~T} 2 \mathrm{SB}$ & 135 & $4.50(0.18)-5.42(0.19)$ & 2.52 & 12.10 & 0.006 \\
\hline T3, T3SB & 135 & $3.58(0.13)-4.75(0.09)$ & 4.08 & 49.00 & $<0.001$ \\
\hline $\mathrm{T} 4, \mathrm{~T} 4 \mathrm{SB}$ & 135 & $2.75(0.09)-3.83(0.10)$ & 3.52 & 60.35 & $<0.001$ \\
\hline T0, T0SB & 150 & $8.33(0.21)-9.50(0.18)$ & 4.08 & 17.50 & 0.002 \\
\hline $\mathrm{T} 1, \mathrm{~T} 1 \mathrm{SB}$ & 150 & $7.66(0.21)-8.33(0.21)$ & 1.33 & 5.00 & 0.05 \\
\hline $\mathrm{T} 2, \mathrm{~T} 2 \mathrm{SB}$ & 150 & $4.66(0.21)-5.66(0.21)$ & 3.00 & 11.25 & 0.007 \\
\hline T3, T3SB & 150 & $3.75(0.09)-4.83(0.10)$ & 3.52 & 60.35 & $<0.001$ \\
\hline $\mathrm{T} 4, \mathrm{~T} 4 \mathrm{SB}$ & 150 & $2.75(0.09)-3.83(0.10)$ & 3.52 & 60.35 & $<0.001$ \\
\hline
\end{tabular}


Table S2. One Way ANOVA showing the comparison of mean values for total plant height of each treatment, where T0, indicates the soil without lithium and bacterial inoculation, T1, T2, T3, T4 indicate the application of different concentration of lithium and TOSB, indicates the soil without lithium application but with the inoculation of bacteria, T1SB, T2SB, T3SB and $T 4 S B$ indicate the different concentrations of lithium with the application of bacterial inoculations

\begin{tabular}{|c|c|c|c|c|c|}
\hline \multicolumn{6}{|c|}{ Total Plant height in different durations } \\
\hline Treatment & Duration (Days) & Mean $( \pm$ SE) & MS & $\mathbf{F}$ & $\boldsymbol{P}$ \\
\hline T0, TOSB & 30 & $39.67(0.55), 49.33(0.42)$ & 280.33 & 191.1 & $<0.001$ \\
\hline T1, T1SB & 30 & $34.00(0.36), 43.00(0.36)$ & 243.0 & 303.75 & $<0.001$ \\
\hline $\mathrm{T} 2, \mathrm{~T} 2 \mathrm{SB}$ & 30 & $30.50(0.18), 37.33(0.42)$ & 140.08 & 221.18 & $<0.001$ \\
\hline T3, T3SB & 30 & $26.660 .42), 3.33(0.21)$ & 133.33 & 200.00 & $<0.001$ \\
\hline $\mathrm{T} 4, \mathrm{~T} 4 \mathrm{SB}$ & 30 & $23.00(0.3), 28.00(0.21)$ & 65.33 & 122.50 & $<0.001$ \\
\hline T0, TOSB & 45 & $61.66(0.55), 67.66(0.5)$ & 108.78 & 57.68 & $<0.001$ \\
\hline $\mathrm{T} 1, \mathrm{~T} 1 \mathrm{SB}$ & 45 & $50.33(1.52), 60.33(0.55)$ & 300.0 & 38.16 & $<0.001$ \\
\hline $\mathrm{T} 2, \mathrm{~T} 2 \mathrm{SB}$ & 45 & $47.33(0.55), 60.0(0.55)$ & 45.3 & 244.64 & $<0.001$ \\
\hline T3, T3SB & 45 & 36.33 (0.55), $56.66(0.42)$ & 1240 & 845 & $<0.0001$ \\
\hline $\mathrm{T} 4, \mathrm{~T} 4 \mathrm{SB}$ & 45 & $36.43(0.55), 52.11(0.49)$ & 768 & 411.6 & $<0.001$ \\
\hline T0, TOSB & 60 & $86.0(0.36), 89.0(1.67)$ & 27.0 & 3.06 & 0.11 \\
\hline $\mathrm{T} 1, \mathrm{~T} 1 \mathrm{SB}$ & 60 & $71.33(3.16), 82.3(0.58)$ & 363.0 & 12.1 & 0.006 \\
\hline $\mathrm{T} 2, \mathrm{~T} 2 \mathrm{SB}$ & 60 & $59.0(0.73), 73.66(0.55)$ & 6455.3 & 254.7 & $<0.001$ \\
\hline T3, T3SB & 60 & $46.3(0.55), 71.0(0.36)$ & 1825 & 1369 & $<0.0001$ \\
\hline $\mathrm{T} 4, \mathrm{~T} 4 \mathrm{SB}$ & 60 & $44.0(0.36), 65.0(0.36)$ & 1323 & 1653 & $<0.0001$ \\
\hline T0, TOSB & 75 & $102.3(1.11), 108.33(1.28)$ & 108.0 & 12.46 & 0.005 \\
\hline $\mathrm{T} 1, \mathrm{~T} 1 \mathrm{SB}$ & 75 & 90.66 (3.6), $99.3(0.76)$ & 225.3 & 5.28 & 0.04 \\
\hline $\mathrm{T} 2, \mathrm{~T} 2 \mathrm{SB}$ & 75 & $76.33(0.91), 97.33$ (0.76) & 1323 & 310.07 & $<0.0001$ \\
\hline T3, T3SB & 75 & $55.0(0.36), 90.33(0.55)$ & 3745 & 2809 & $<0.0001$ \\
\hline $\mathrm{T} 4, \mathrm{~T} 4 \mathrm{SB}$ & 75 & $51.33(0.55), 87.66(0.61)$ & 3960 & 2121 & $<0.0001$ \\
\hline T0, TOSB & 90 & $118.33(0.55), 127.3(0.91)$ & 243 & 70.1 & $<0.01$ \\
\hline T1, T1SB & 90 & $108.3(4.5), 119.6(0.91)$ & 385.3 & 5.92 & 0.035 \\
\hline $\mathrm{T} 2, \mathrm{~T} 2 \mathrm{SB}$ & 90 & $86.66(0.55), 112.0(0.96)$ & 1925 & 515.7 & $<0.0001$ \\
\hline T3, T3SB & 90 & $65.21(0.35), 102.3(0.85)$ & 4107 & 2200 & $<0.0001$ \\
\hline $\mathrm{T} 4, \mathrm{~T} 4 \mathrm{SB}$ & 90 & $64.33(0.41), 98.0(0.36)$ & 3400 & 2550 & $<0.001$ \\
\hline T0, TOSB & 105 & $128.3(0.76), 139.3(0.91)$ & 363 & 85.0 & $<0.001$ \\
\hline $\mathrm{T} 1, \mathrm{~T} 1 \mathrm{SB}$ & 105 & $123.6(2.0), 133.0(0.96)$ & 261.3 & 17.5 & 0.002 \\
\hline $\mathrm{T} 2, \mathrm{~T} 2 \mathrm{SB}$ & 105 & 99.0 (0.73), 126.70 .61$)$ & 2296 & 906 & $<0.0001$ \\
\hline T3, T3SB & 105 & $76.0(0.73), 111.3(0.55)$ & 3745 & 1478 & $<0.0001$ \\
\hline $\mathrm{T} 4, \mathrm{~T} 4 \mathrm{SB}$ & 105 & $73.0(0.42), 110.3(0.51)$ & 4256 & 2902 & $<0.0001$ \\
\hline $\mathrm{T} 0, \mathrm{~T} 0 \mathrm{SB}$ & 120 & $138.3(0.58), 149.6(0.76)$ & 385.3 & 144.5 & $<0.001$ \\
\hline $\mathrm{T} 1, \mathrm{~T} 1 \mathrm{SB}$ & 120 & $130.0(0.96), 147.0(0.73)$ & 867.0 & 195.0 & $<0.001$ \\
\hline $\mathrm{T} 2, \mathrm{~T} 2 \mathrm{SB}$ & 120 & $109.3(1.2), 138.0(0.36)$ & 2465 & 462 & $<0.0001$ \\
\hline $\mathrm{T} 3, \mathrm{~T} 3 \mathrm{SB}$ & 120 & $86.0(0.96), 121.0(0.63)$ & 3675 & 918 & $<0.001$ \\
\hline $\mathrm{T} 4, \mathrm{~T} 4 \mathrm{SB}$ & 120 & $88.0(0.36), 117.3(0.55)$ & 2581 & 1936 & $<0.001$ \\
\hline T0, TOSB & 135 & $144.6(0.55), 157.3(0.91)$ & 481.3 & 138.8 & $<0.001$ \\
\hline $\mathrm{T} 1, \mathrm{~T} 1 \mathrm{SB}$ & 135 & $136.0(0.36), 159.6(0.55)$ & 1680 & 1260 & $<0.001$ \\
\hline $\mathrm{T} 2, \mathrm{~T} 2 \mathrm{SB}$ & 135 & $117.3(0.76), 144.6(0.55)$ & 2241 & 840.5 & $<0.001$ \\
\hline T3, T3SB & 135 & $96.0(1.0), 127.3(0.49)$ & 2945 & 788 & $<0.001$ \\
\hline $\mathrm{T} 4, \mathrm{~T} 4 \mathrm{SB}$ & 135 & $93.0(0.36), 124.0(0.40)$ & 2883 & 3603 & $<0.001$ \\
\hline T0, TOSB & 150 & $150.0(0.73), 168.3(0.58)$ & 1008 & 398 & $<0.001$ \\
\hline T1, T1SB & 150 & $141.6(0.91), 168.3(0.50)$ & 2133 & 615 & $<0.001$ \\
\hline $\mathrm{T} 2, \mathrm{~T} 2 \mathrm{SB}$ & 150 & $123.6(0.91), 151.6(0.41)$ & 2352 & 6778.4 & $<0.001$ \\
\hline T3, T3SB & 150 & $106.0(0.63), 133.0(0.36)$ & 2187 & 1366 & $<0.0001$ \\
\hline T4, T4SB & 150 & $99.0(0.36), 129.0(0.29)$ & 2700 & 3375 & $<0.0001$ \\
\hline
\end{tabular}


Table S3. One Way ANOVA showing the comparison of mean values of number of Panicles, Panicle length, number of grains per Panicle and total number of grains per plant. Where TO, indicates the soil without lithium and bacterial inoculation, T1, T2, T3, T4 indicate the application of different concentration of lithium and TOSB, indicates the soil without lithium application but with the inoculation of bacteria, T1SB, T2SB, T3SB and T4SB indicate the different concentrations of lithium with the application of bacterial inoculations

\begin{tabular}{|c|c|c|c|c|}
\hline \multicolumn{5}{|c|}{ Number of Panicles } \\
\hline Treatment & Mean $( \pm$ SE) & MS & $\mathbf{F}$ & $P$ \\
\hline $\mathrm{T} 1, \mathrm{~T} 1 \mathrm{SB}$ & $4.66(0.33), 5.33(0.33)$ & 0.67 & 2.00 & 0.23 \\
\hline $\mathrm{T} 2, \mathrm{~T} 2 \mathrm{SB}$ & $3.66(0.33), 5.66(0.33)$ & 6.00 & 188.00 & 0.013 \\
\hline $\mathrm{T} 3, \mathrm{~T} 3 \mathrm{SB}$ & $2.33(0.33), 4.33(0.33)$ & 6.00 & 18.00 & 0.013 \\
\hline $\mathrm{T} 4, \mathrm{~T} 4 \mathrm{SB}$ & $1.33(0.33), 2.330 .33)$ & 1.50 & 4.50 & 0.10 \\
\hline \multicolumn{5}{|c|}{$\begin{array}{r}\text { Panicle Length } \\
\end{array}$} \\
\hline T0, T0SB & $23.0(0.5), 26.0(0.57)$ & 13.50 & 13.5 & 0.021 \\
\hline $\mathrm{T} 1, \mathrm{~T} 1 \mathrm{SB}$ & $21.3(0.88), 24.0(0.57)$ & 10.66 & 6.40 & 0.065 \\
\hline $\mathrm{T} 2, \mathrm{~T} 2 \mathrm{SB}$ & $20.66(0.66), 23.00(0.58)$ & 8.16 & 7.00 & 0.057 \\
\hline T3, T3SB & $19.00(0.6), 21.33(0.88)$ & 8.16 & 4.90 & 0.091 \\
\hline $\mathrm{T} 4, \mathrm{~T} 4 \mathrm{SB}$ & $17.0(0.51), 20.33(0.90)$ & 16.7 & 10.00 & 0.034 \\
\hline \multicolumn{5}{|c|}{ Number of grains per Panicle } \\
\hline T0, TOSB & $371.66(4.41), 445.0(2.88)$ & 8066 & 193.6 & $<0.001$ \\
\hline $\mathrm{T} 1, \mathrm{~T} 1 \mathrm{SB}$ & $305.00(2.88), 381.66(4.41)$ & 8816 & 211 & $<0.001$ \\
\hline $\mathrm{T} 2, \mathrm{~T} 2 \mathrm{SB}$ & 291.66 (4.41), $346.0(3.05)$ & 4428 & 102.5 & $<0.001$ \\
\hline $\mathrm{T} 3, \mathrm{~T} 3 \mathrm{SB}$ & $285.0(2.88), 327.6(1.45)$ & 2730 & 174.2 & $<0.001$ \\
\hline $\mathrm{T} 4, \mathrm{~T} 4 \mathrm{SB}$ & $271.6(4.41), 307.6(1.46)$ & 1944 & 60.12 & 0.001 \\
\hline \multicolumn{5}{|c|}{ Grains per plant } \\
\hline T0, T0SB & $2446.6(31.79), 3458.3(22.04)$ & 135204 & 683.57 & $<0.001$ \\
\hline $\mathrm{T} 1, \mathrm{~T} 1 \mathrm{SB}$ & 2050 (28.68), 2483.33 (12.09) & 281666 & 192.04 & $<0.001$ \\
\hline $\mathrm{T} 2, \mathrm{~T} 2 \mathrm{SB}$ & $1483.3(8.81),, 1780.0(11.54)$ & 132016 & 416.89 & $<0.001$ \\
\hline T3, T3SB & 986.67 (8.82), 1383 (8.89) & 236016 & 1011 & $<0.001$ \\
\hline $\mathrm{T} 4, \mathrm{~T} 4 \mathrm{SB}$ & $583.33(8.81), 945.0(2.88)$ & 196204 & 1519 & $<0.001$ \\
\hline
\end{tabular}

Table S4. One Way ANOVA showing the comparison of mean values for Photosynthetic rate, transpiration, and stomatal conductance for each treatment in three different durations. Where T0, indicates the soil without lithium and bacterial inoculation, T1, T2, T3, T4 indicate the application of different concentration of lithium and TOSB, indicates the soil without lithium application but with the inoculation of bacteria, T1SB, T2SB, T3SB and T4SB indicate the different concentrations of lithium with the application of bacterial inoculations

\begin{tabular}{c|c|c|c|c|c}
\hline \multicolumn{7}{c}{ Photosynthetic rate } \\
\hline Treatment & Duration (Days) & Mean $( \pm$ SE) & MS & F & $P$ \\
\hline T0, T0SB & Initial Week & $14.73(0.01), 15.23(0.01)$ & 1.8 & 2317 & $<0.001$ \\
T1, T1SB & Initial Week & $12.65(0.02), 13.57(0.02)$ & 1.25 & 987 & $<0.001$ \\
T2, T2SB & Initial Week & $11.7(0.01), 12.28(0.001)$ & 0.385 & 888 & $<0.001$ \\
T3, T3SB & Initial Week & $10.93(0.03), 11.67(0.01)$ & 0.700 & 362.28 & $<0.001$ \\
T4, T4SB & Initial Week & $9.83(0.01), 10.43(0.001)$ & 0.634 & 1086 & $<0.001$ \\
\hline
\end{tabular}




\begin{tabular}{|c|c|c|c|c|c|}
\hline \multicolumn{6}{|c|}{ Photosynthetic rate } \\
\hline Treatment & Duration (Days) & Mean $( \pm$ SE) & MS & $\mathbf{F}$ & $\boldsymbol{P}$ \\
\hline T0, TOSB & Flowering time & 26.83 (0.08), $30.10(0.01)$ & 16.07 & 1369 & $<0.001$ \\
\hline $\mathrm{T} 1, \mathrm{~T} 1 \mathrm{SB}$ & Flowering time & $24.12(0.01), 26.83(0.01)$ & 10.98 & 19392 & $<0.001$ \\
\hline $\mathrm{T} 2, \mathrm{~T} 2 \mathrm{SB}$ & Flowering time & $22.90(0.01), 24.16(0.01)$ & 2.35 & 199.96 & $<0.001$ \\
\hline T3, T3SB & Flowering time & $22.01(0.01), 22.57(0.01)$ & 0.48 & 810.47 & $<0.001$ \\
\hline $\mathrm{T} 4, \mathrm{~T} 4 \mathrm{SB}$ & Flowering time & $18.01(0.01), 21.02(0.01)$ & 13.56 & 31292 & $<0.001$ \\
\hline T0, T0SB & Seed formation & $22.26(0.14), 25.10(0.06)$ & 12.42 & 328.49 & $<0.001$ \\
\hline $\mathrm{T} 1, \mathrm{~T} 1 \mathrm{SB}$ & Seed formation & $19.0(0.01), 22.0(0.01)$ & 13.37 & 50512 & $<0.001$ \\
\hline $\mathrm{T} 2, \mathrm{~T} 2 \mathrm{SB}$ & Seed formation & $18.0(0.01), 20.0(0.00)$ & 5.94 & 23760 & $<0.001$ \\
\hline T3, T3SB & Seed formation & $18.0(0.00), 19.01(0.01)$ & 1.54 & 11552 & $<0.001$ \\
\hline $\mathrm{T} 4, \mathrm{~T} 4 \mathrm{SB}$ & Seed formation & $14.0(0.01), 17.02(0.01)$ & 13.44 & 26013 & $<0.001$ \\
\hline \multicolumn{6}{|c|}{ Transpiration } \\
\hline T0, T0SB & Initial Week & $2.92(0.01), 3.11(0.00)$ & 0.058 & 183.21 & $<0.001$ \\
\hline $\mathrm{T} 1, \mathrm{~T} 1 \mathrm{SB}$ & Initial Week & $2.11(0.00), 2.41(0.01)$ & 0.138 & 828 & $<0.001$ \\
\hline $\mathrm{T} 2, \mathrm{~T} 2 \mathrm{SB}$ & Initial Week & 1.90 (0.00), $2.00(0.00)$ & 0.016 & 961.0 & $<0.001$ \\
\hline $\mathrm{T} 3, \mathrm{~T} 3 \mathrm{SB}$ & Initial Week & $1.50(0.01), 1.81(0.01)$ & 0.138 & 637.0 & $<0.001$ \\
\hline $\mathrm{T} 4, \mathrm{~T} 4 \mathrm{SB}$ & Initial Week & $1.31(0.00), 1.45(0.01)$ & 0.032 & 276.57 & $<0.001$ \\
\hline T0, T0SB & Flowering time & $5.81(0.01), 6.31(0.01)$ & 0.365 & 1152 & $<0.001$ \\
\hline $\mathrm{T} 1, \mathrm{~T} 1 \mathrm{SB}$ & Flowering time & $4.11(0.01), 4.61(0.01)$ & 0.3775 & 2045 & $<0.001$ \\
\hline $\mathrm{T} 2, \mathrm{~T} 2 \mathrm{SB}$ & Flowering time & $3.91(0.00), 4.01(0.00)$ & 0.015 & 150.0 & $<0.001$ \\
\hline $\mathrm{T} 3, \mathrm{~T} 3 \mathrm{SB}$ & Flowering time & $3.71(0.00), 3.80(0.00)$ & 0.0131 & 196.0 & $<0.001$ \\
\hline $\mathrm{T} 4, \mathrm{~T} 4 \mathrm{SB}$ & Flowering time & $2.91(0.01), 3.01(0.00)$ & 0.014 & 84.10 & $<0.001$ \\
\hline $\mathrm{T} 0, \mathrm{~T} 0 \mathrm{SB}$ & Seed formation & $3.60(0.01), 4.01(0.01)$ & 0.248 & 13353 & $<0.001$ \\
\hline $\mathrm{T} 1, \mathrm{~T} 1 \mathrm{SB}$ & Seed formation & $3.01(0.00), 3.61(0.00)$ & 0.540 & 5400.0 & $<0.001$ \\
\hline $\mathrm{T} 2, \mathrm{~T} 2 \mathrm{SB}$ & Seed formation & $3.023(0.00), 3.00(0.00)$ & 0.00 & 18.0 & 0.013 \\
\hline $\mathrm{T} 3, \mathrm{~T} 3 \mathrm{SB}$ & Seed formation & $2.80(0.00), 3.00(0.00)$ & 0.06 & 1800 & $<0.001$ \\
\hline $\mathrm{T} 4, \mathrm{~T} 4 \mathrm{SB}$ & Seed formation & $2.82(0.01), 2.91(0.00)$ & 0.0104 & 28.40 & 0.006 \\
\hline \multicolumn{6}{|c|}{ Stomatal Conductance } \\
\hline $\mathrm{T} 0, \mathrm{TOSB}$ & Initial Week & $0.131(0.00), 0.140(0.00)$ & 0.00 & 168.2 & $<0.001$ \\
\hline $\mathrm{T} 1, \mathrm{~T} 1 \mathrm{SB}$ & Initial Week & $0.130(0.00), 0.121(0.00)$ & 0.00 & 81.0 & $<0.001$ \\
\hline $\mathrm{T} 2, \mathrm{~T} 2 \mathrm{SB}$ & Initial Week & $0.091((0.00), 0.10(0.00)$ & 0.00 & 42.5 & 0.003 \\
\hline $\mathrm{T} 3, \mathrm{~T} 3 \mathrm{SB}$ & Initial Week & 0.07 (0.00), $0.08(0.00)$ & 0.00 & 64.05 & 0.001 \\
\hline $\mathrm{T} 4, \mathrm{~T} 4 \mathrm{SB}$ & Initial Week & $0.061(0.00), 0.072(0.00)$ & 0.00 & 90.75 & $<0.001$ \\
\hline T0, T0SB & Flowering time & $0.272(0.001), 0.291(0.001)$ & 0.000 & 196.0 & $<0.001$ \\
\hline $\mathrm{T} 1, \mathrm{~T} 1 \mathrm{SB}$ & Flowering time & $0.250(0.00), 0.271(0.00)$ & 0.000 & 496.12 & $<0.001$ \\
\hline $\mathrm{T} 2, \mathrm{~T} 2 \mathrm{SB}$ & Flowering time & $0.211(0.00), 0.232(0.00)$ & 0.00 & 240.25 & $<0.001$ \\
\hline $\mathrm{T} 3, \mathrm{~T} 3 \mathrm{SB}$ & Flowering time & $0.91(0.00), 0.203(0.00)$ & 0.00 & 13.29 & 0.022 \\
\hline $\mathrm{T} 4, \mathrm{~T} 4 \mathrm{SB}$ & Flowering time & $0.171(0.00), 0.180(0.00)$ & 0.00 & 420.50 & $<0.001$ \\
\hline T0, T0SB & Seed formation & $0.20(0.00), 0.241(0.00)$ & 0.00 & 121.45 & $<0.001$ \\
\hline $\mathrm{T} 1, \mathrm{~T} 1 \mathrm{SB}$ & Seed formation & $0.200(0.00), 0.191(0.00)$ & 0.00 & 168.20 & $<0.001$ \\
\hline $\mathrm{T} 2, \mathrm{~T} 2 \mathrm{SB}$ & Seed formation & $0.181(0.00), 0.190(0.00)$ & 0.00 & 196.0 & $<0.001$ \\
\hline $\mathrm{T} 3, \mathrm{~T} 3 \mathrm{SB}$ & Seed formation & $0.181(0.00), 0.192(0.00)$ & 0.00 & 72.25 & 0.001 \\
\hline $\mathrm{T} 4, \mathrm{~T} 4 \mathrm{SB}$ & Seed formation & $0.161(0.00), 0.181(0.00)$ & 0.00 & 531.57 & $<0.001$ \\
\hline
\end{tabular}


Table S5. One Way ANOVA showing the comparison of mean values of shoot fresh weight, root fresh weight, shoot dry weight, root dry weight, specific shoot length, and specific root length across different treatments. Where T0, indicates the soil without lithium and bacterial inoculation, T1, T2, T3, T4 indicate the application of different concentration of lithium and $T O S B$, indicates the soil without lithium application but with the inoculation of bacteria, T1SB, $T 2 S B, T 3 S B$ and T4SB indicate the different concentrations of lithium with the application of bacterial inoculations

\section{Shoot Fresh weight}

\begin{tabular}{|c|c|c|c|c|}
\hline Treatment & Mean $( \pm$ SE) & MS & $\mathbf{F}$ & $\boldsymbol{P}$ \\
\hline $\mathrm{T} 1, \mathrm{~T} 1 \mathrm{SB}$ & $128.7(0.17), 134.20(0.41)$ & 44.82 & 146.2 & $<0.001$ \\
\hline $\mathrm{T} 2, \mathrm{~T} 2 \mathrm{SB}$ & $120.21(1.31), 129.6(0.40)$ & 133.95 & 47.13 & 0.002 \\
\hline $\mathrm{T} 3, \mathrm{~T} 3 \mathrm{SB}$ & $70.66(0.20), 96.90(0.057)$ & 1032.0 & 14770 & $<0.001$ \\
\hline $\mathrm{T} 4, \mathrm{~T} 4 \mathrm{SB}$ & $48.56(0.29), 70.13(0.24)$ & 697.68 & 3195.48 & $<0.001$ \\
\hline \multicolumn{5}{|c|}{ Root Fresh weight } \\
\hline T0, TOSB & $19.25(0.081), 19.40(0.098)$ & 0.0353 & 1.44 & 0.296 \\
\hline $\mathrm{T} 1, \mathrm{~T} 1 \mathrm{SB}$ & $18.57(0.29), 19.39(0.058)$ & 1.009 & 7.52 & 0.052 \\
\hline $\mathrm{T} 2, \mathrm{~T} 2 \mathrm{SB}$ & $13.92(0.03), 16.64(0.26)$ & 11.12 & 107.40 & $<0.001$ \\
\hline T3, T3SB & $12.53(0.29), 13.43(0.23)$ & 1.21 & 5.83 & 0.073 \\
\hline $\mathrm{T} 4, \mathrm{~T} 4 \mathrm{SB}$ & $10.73(0.17), 11.54(0.02)$ & 1.067 & 23.82 & 0.008 \\
\hline \multicolumn{5}{|c|}{ Shoot Dry weight } \\
\hline T0, T0SB & $45.33(0.26), 45.87(0.057)$ & 0.443 & 3.96 & 0.11 \\
\hline $\mathrm{T} 1, \mathrm{~T} 1 \mathrm{SB}$ & $43.25(0.14), 45.06(0.12)$ & 4.95 & 93.55 & $<0.001$ \\
\hline $\mathrm{T} 2, \mathrm{~T} 2 \mathrm{SB}$ & $40.00(0.57), 43.63(0.27)$ & 19.83 & 32.57 & 0.005 \\
\hline $\mathrm{T} 3, \mathrm{~T} 3 \mathrm{SB}$ & $32.50(0.26), 36.60(0.306)$ & 25.21 & 102.91 & $<0.001$ \\
\hline $\mathrm{T} 4, \mathrm{~T} 4 \mathrm{SB}$ & $19.65(0.038), 25.56(0.29)$ & 52.45 & 391.76 & $<0.001$ \\
\hline \multicolumn{5}{|c|}{ Root Dry weight } \\
\hline T0, T0SB & $14.17(0.00), 14.27(0.024)$ & 0.015 & 15.25 & 0.017 \\
\hline $\mathrm{T} 1, \mathrm{~T} 1 \mathrm{SB}$ & $13.44(0.19), 12.20(0.05)$ & 2.29 & 37.0 & 0.004 \\
\hline $\mathrm{T} 2, \mathrm{~T} 2 \mathrm{SB}$ & $10.59(0.26), 12.45(0.18)$ & 5.17 & 32.36 & 0.005 \\
\hline $\mathrm{T} 3, \mathrm{~T} 3 \mathrm{SB}$ & $9.70(0.55), 10.57(0.22)$ & 1.127 & 2.11 & 0.22 \\
\hline $\mathrm{T} 4, \mathrm{~T} 4 \mathrm{SB}$ & $7.58(0.28), 8.03(0.01)$ & 0.299 & 2.415 & 0.195 \\
\hline \multicolumn{5}{|c|}{\begin{tabular}{|c|} 
Specific Shoot length \\
\end{tabular}} \\
\hline T0, TOSB & $150.00(1.15), 168.3(0.88)$ & 504.16 & 159.21 & $<0.001$ \\
\hline $\mathrm{T} 1, \mathrm{~T} 1 \mathrm{SB}$ & $141.66(1.45), 168.33(0.88)$ & 1066 & 246 & $<0.001$ \\
\hline $\mathrm{T} 2, \mathrm{~T} 2 \mathrm{SB}$ & $123.66(1.45), 151.66(0.88)$ & 1176 & 271.38 & $<0.001$ \\
\hline $\mathrm{T} 3, \mathrm{~T} 3 \mathrm{SB}$ & $106.00(1.00), 133.0(0.57)$ & 1093 & 546.75 & $<0.001$ \\
\hline $\mathrm{T} 4, \mathrm{~T} 4 \mathrm{SB}$ & $99.0(0.57), 129.0(0.57)$ & 1350 & 1350 & $<0.001$ \\
\hline \multicolumn{5}{|c|}{ Specific Root length } \\
\hline T0, TOSB & $25.0(0.57), 28.11(0.61)$ & 14.10 & 15.55 & 0.02 \\
\hline $\mathrm{T} 1, \mathrm{~T} 1 \mathrm{SB}$ & $23.40(0.37), 27.23(0.29)$ & 21.88 & 6.70 & 0.001 \\
\hline $\mathrm{T} 2, \mathrm{~T} 2 \mathrm{SB}$ & $21.05(0.53), 24.40(0.15)$ & 13.38 & 29.17 & 0.006 \\
\hline $\mathrm{T} 3, \mathrm{~T} 3 \mathrm{SB}$ & $17.42(0.29),, 22.08(0.32)$ & 32.48 & 111.336 & $<0.001$ \\
\hline $\mathrm{T} 4, \mathrm{~T} 4 \mathrm{SB}$ & $16.80(0.41), 20.37(0.06)$ & 19.11 & 71.69 & 0.001 \\
\hline
\end{tabular}


Table S6. One Way ANOVA showing the comparison of mean values of chlorophyll a, chlorophyll $b$, and total chlorophyll across different treatments. Where T0, indicates the soil without lithium and bacterial inoculation, T1, T2, T3, T4 indicate the application of different concentration of lithium and TOSB, indicates the soil without lithium application but with the inoculation of bacteria, T1SB, T2SB, T3SB and T4SB indicate the different concentrations of lithium with the application of bacterial inoculations

\begin{tabular}{c|c|c|c|c}
\hline \multicolumn{5}{c}{ Chlorophyll a } \\
\hline Treatment & Mean ( \pm SE) & MS & F & $\boldsymbol{P}$ \\
\hline T1, T1SB & $1.20(0.15), 1.06(0.001)$ & 0.028 & 0.855 & 0.408 \\
T2, T2SB & $1.01(0.001), 1.02(0.001)$ & 0.000 & 45.0 & 0.003 \\
T3, T3SB & $0.98(0.00), 1.009(0.004)$ & 0.001 & 30.48 & 0.005 \\
T4, T4SB & $0.68(0.00), 0.85(0.00)$ & 0.043 & 26112 & $<0.001$ \\
\hline \multicolumn{5}{c}{ Chlorophyll b } \\
\hline T0, T0SB & $0.703(0.00), 0.703(0.00)$ & & & 1.00 \\
T1, T1SB & $0.60(0.001), 0.6820 .001)$ & 0.0096 & 1873 & $<0.001$ \\
T2, T2SB & $0.512(0.00), 0.531(0.00)$ & 0.000 & 336 & $<0.001$ \\
T3, T3SB & $0.44(0.00), 0.560 .00)$ & 0.021 & 9257 & $<0.001$ \\
T4, T4SB & $0.23(0.00), 0.34(0.00)$ & 0.0181 & 18150 & $<0.001$ \\
\hline \multicolumn{5}{c}{ Total Chlorophyll } \\
\hline T0, T0SB & $1.80(0.003), 2.03(0.03)$ & 0.079 & 47.13 & 0.002 \\
T1, T1SB & $1.71(0.005), 1.75(0.00)$ & 0.002 & 51.53 & 0.002 \\
T2, T2SB & $1.55(0.00), 1.61(0.001)$ & 0.0057 & 84.09 & $<0.001$ \\
T3, T3SB & $1.41(0.005), 1.57(0.002)$ & 0.039 & 705.37 & $<0.001$ \\
T4, T4SB & $0.91(0.00), 1.22(0.01)$ & 0.143 & 714.322 & $<0.001$ \\
\hline
\end{tabular}

Table S7. One Way ANOVA showing the comparison of mean values of lithium concentration in shoot, lithium concentration in root, and lithium concentration in grains. Where TO, indicates the soil without lithium and bacterial inoculation, T1, T2, T3, T4 indicate the application of different concentration of lithium and TOSB, indicates the soil without lithium application but with the inoculation of bacteria, T1SB, T2SB, T3SB and T4SB indicate the different concentrations of lithium with the application of bacterial inoculations

\begin{tabular}{|c|c|c|c|c|}
\hline \multicolumn{5}{|c|}{ Lithium Concentration (Shoot) } \\
\hline Treatment & Mean $( \pm$ SE) & MS & $\mathbf{F}$ & $P$ \\
\hline $\mathrm{T} 1, \mathrm{~T} 1 \mathrm{SB}$ & $1288.68(0.70), 28.70(0.43)$ & 15000 & 18000 & $<0.0001$ \\
\hline $\mathrm{T} 2, \mathrm{~T} 2 \mathrm{SB}$ & $667.0(1.52), 57.00(0.61)$ & 55815 & 139537 & $<0.0001$ \\
\hline T3, T3SB & $978.66(1.2), 125.0(0.57)$ & 1093120 & 409920 & $<0.0001$ \\
\hline \multicolumn{5}{|c|}{$\begin{array}{c}\text { Lithium Concentration (Root) } \\
\end{array}$} \\
\hline T0, TOSB & $39.0(0.6), 8.33(0.33)$ & 1410 & 2116 & $<0.0001$ \\
\hline $\mathrm{T} 1, \mathrm{~T} 1 \mathrm{SB}$ & $83.0(0.61), 17.66(0.355)$ & 6402 & 9604 & $<0.001$ \\
\hline $\mathrm{T} 2, \mathrm{~T} 2 \mathrm{SB}$ & $378.33(0.88), 36.0(0.60)$ & 17755788 & 105472 & $<0.0001$ \\
\hline T3, T3SB & $566.35(0.88), 79.35(0.67)$ & 355753 & 194047 & $<0.0001$ \\
\hline \multicolumn{5}{|c|}{ Lithium Concentration (Grains) } \\
\hline T0, T0SB & $3.33(0.25), 1.00(0.00)$ & 8.16 & 49.0 & 0.002 \\
\hline $\mathrm{T} 1, \mathrm{~T} 1 \mathrm{SB}$ & $7.33(0.31), 2.00(0.00)$ & 42.66 & 256.0 & $<0.001$ \\
\hline $\mathrm{T} 2, \mathrm{~T} 2 \mathrm{SB}$ & $18.66(0.71), 3.33(0.21)$ & 352.66 & 423.20 & $<0.001$ \\
\hline T3, T3SB & $28.66(0.66), 5.33(0.33)$ & 816.67 & 980.00 & $<0.001$ \\
\hline
\end{tabular}

